УДК 82

ББК $83+83.3(05 \mathrm{I}) 64-6 \mathrm{I} 2$
НАЦИОНАЛЬНАЯ САМОБЫТНОСТЬ

И ХУДОЖЕСТВЕННАЯ ЦЕННОСТЬ:

К ВОПРОСУ О ВЗАИМОДОПОЛНЯЕМОСТИ

ЭТНОКУЛЬТУРНОГО ДИСКУРСА И АКСИОЛОГИЧЕСКОГО ПОДХОДА

\author{
(C) 2018 г. К.К. Султанов \\ Институт мировой литературы \\ им. А.М. Горького Российской академии наук, \\ Москва, Россия \\ Дата поступления статьи: I4 декабря 2017 г. \\ Дата публикации: 25 июня 2018 г.
}

DOI: I0.22455/2500-4247-2018-3-2-230-25I

Аннотация: В статье рассматривается методологически важная проблема корреляции этнокультурного и аксиологического подхода. Ослабление интереса к структурно-семантической сложности произведения, девальвация ценностных критериев отводят периферийную роль решающему фактору художественной результативности. Принцип эстетической избирательности и литературоведческий модус осмысления функциональной роли этнокультурных реалий остаются в тени ценностного релятивизма. Активизация ценностно-смыслового подхода в рамках литературоведческого дискурса позволит восстановить статус «художественной ценности» как значимой моделирующей категории и с большим вниманием относиться к семантической взаимодополняемости «национального своеобразия» и «художественной ценности». Смена или переоценка ценностей преобразует и модифицирует самочувствие литературы, открывая новый горизонт самовыражения и миропонимания и выявляя продуктивную борьбу устоявшихся и нарождающихся смыслов, традиционалистских установок и перспективных художественных интенций. В современном литературоведении, ориентированном на изучение литератур народов России, очевиден спрос на полноту реконструкции национальной литературы и, следовательно, на преодоление существующего разрыва между аксиологическим и этнокультурным аспектами анализа.

Ключевые слова: художественная ценность, этнокультурная доминанта, аксиологический подход, ценностные критерии, значимость, реконструкция, переоценка ценностей.

Информация об авторе: Казбек Камилович Султанов - доктор филологических наук, профессор МГУ им. М.В. Ломоносова, Институт мировой литературы им. А.М. Горького Российской академии наук, ул. Поварская, д. 25 а, І2І1069 г. Москва, Россия.

E-mail: sulkaz@inbox.ru

Для цитирования: Султанов К.К. Национальная самобытность и художественная ценность: к вопросу о взаимодополняемости этнокультурного дискурса и аксиологического подхода // Studia Litterarum. 2018. Т. 3, № 2. С. 230-25I. DOI: I0.22455/2500-4247-20I8-3-2-230-25I 


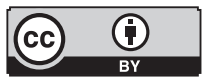

This is an open access article distributed under the Creative Commons Attribution 4.0 International (CC BY 4.0)

\section{NATIONAL SPECIFICITY AND ARTISTIC VALUE: AT THE CROSSROADS OF ETHNOCULTURAL DISCOURSE AND AXIOLOGICAL CRITIQUE}

\author{
(C) 20I8. K.K. Sultanov \\ A.M. Gorky Institute of World Literature \\ of the Russian Academy of Sciences, Moscow, Russia \\ Received: December I4, 2017 \\ Date of publication: June 25, 2018
}

\begin{abstract}
The article discusses correlation of ethnic, cultural, and axiological approaches as a methodologically relevant problem in literary studies. The weakening interest in the structural and semantic complexity of the literary work and devaluation of the assertion criteria assign a peripheral role to the creative factor in art. As a result, the principle of aesthetic selectivity and the literary approach to the functional role of ethnocultural realities remain in the shadows of axiological relativism. The essay intends to restore the status of "artistic value" as a significant category in literary studies by practicing axiological approach within the literary discourse; it also invites to pay special attention to the semantic complementarity of "national specificity" and "artistic value" respectively. A change of values affects and modifies the state of literature and its self-awareness by opening a new horizon of self-expression and modelling a certain worldview; it reveals productive struggle of established and emerging meanings, traditionalist attitudes and promising artistic intentions. In contemporary literary criticism oriented at the study of the literatures of the peoples of Russia, there is a demand for the reconstruction and reevaluation of national literatures. Such criticism seeks to overcome the existing gap between axiological and cultural aspects of textual analysis.
\end{abstract}

Keywords: artistic value, ethnic dominant, axiological approach, axiological criteria, significance, reconstruction, reevaluation.

Information about the author: Kazbek K. Sultanov, DSc in Philology, Professor, Lomonosov Moscow State University, A.M. Gorky Institute of World Literature of the Russian Academy of Sciences, Povarskaya 25 a, I21069 Moscow, Russia.

E-mail: sulkaz@inbox.ru

For citation: Sultanov K.K. National Specificity and Artistic Value: At the Crossroads of Ethnocultural Discourse and Axiological Critique. Studia Litterarum, 20I8, vol. 3, no 2, pp. 230-25I. (In Russ.) DOI: IO.22455/2500-4247-20I8-3-2-230-25I 
Вынесенная в название проблема соотносится с одной из самых насущных задач современного гуманитарного знания - преодоление ценностного релятивизма, постулирующего в качестве новейшей культурной нормы установку на обесценивание всего и вся. Неразличение ценностей и сопутствующая ему инфляция критериев нашли свое отражение и в литературоведческом дискурсе, трансформируясь в «эстетику» неотличимости подлинного и мнимого, ценности и подделки, «живого» и «мертвого» в литературе.

Сегодня одним из последствий кардинального изменения общественного статуса литературы стало преобладание факта издания книги, раскрученного в формате рекламы, над читательской рефлексией и критико-литературоведческой оценкой: своевременный и желательно наступательный ритуал презентации книги или фильма куда важнее их реального художественного веса. Это, к сожалению, общий тренд: произведение перестало идентифицироваться как художественная ценность, национальная литература превращается в собрание НЛО - эстетически неопознанных литературных объектов.

Ценностная глухота, которая «правит бал» и аннигилирует идею эстетической избирательности, обнаруживает признаки парадоксального сближения с давним революционным покушением апологетов классового подхода на приоритетность художественных ценностей: «общий критерий ценности - это критерий полезности для практики пролетариата» [9, с. I4I]. Совсем не случайно Н. Бердяев уличал марксистов в том, что с ними «нельзя даже говорить об иерархии ценностей, ибо они не принимают самой постановки вопроса о ценности, для них существует только необходимость, польза, благо...». Выдвигая тезис об «определении ценностей» как «транс- 
цендентальной функции сознания», философ подчеркивал, что «творчество духовной культуры всегда означает соблюдение иерархии ценностей, единственной иерархии, которая может быть оправдана» $[7$, с. 273, 278].

Непроявленность «ценностного веса» произведения или «конкретной архитектоники ценностного переживания мира» [6, с. I64], ослабление интереса к структурно-семантической сложности произведения превращают роман или стихотворение в «заложника» этнокультурных детерминаций, оттесняя собственно эстетические критерии на периферию анализа. Актуализация этнической специфики, взятой в ее предзаданности, становится доминирующей, вычленение «этнокорня» приобретает статус идентификатора ценности произведения, обрекая аксиологический подход на периферийное сопровождение превалирующей этнокультурной парадигмы.

Судя по некоторым литературоведческим интерпретациям (на материале, например, северокавказских литератур), прилежное воспроизведение этнокультурных реалий, императивность «местного колорита» являются чуть ли не высшей целью и конечной инстанцией писательских усилий.

Закономерно и естественно присутствуя в произведении, эти реалии могут оставаться на уровне «остановленной этнографии» помимо и вне их осмысления в системе внутритекстовых связей и сцеплений, жанрово-стилевой функциональности, когда ни один компонент художественной целостности не может быть понят иначе, чем в соотнесении с другими компонентами. Кроме того, избыточность этнокультурных коннотаций ограничивает сферу действия и восприятия возможных смысловых интенций, никак не связанных с этнокультурной отличительностью. При таком сужении горизонта анализа за скобками остается фактор художественной результативности, который есть нечто большее, чем просто добросовестная верность локальной или региональной специфике.

Размытость литературоведческого модуса осмысления функциональной роли этнокультурных реалий в произведении как «второй реальности» дает знать о себе и в распространенном, хотя и спорном, использовании понятия «этническая литература».

Если перед нами действительно «этническая литература», то это состояние следует охарактеризовать как предлитературное или долитературное. Если же переход от фольклорного мироощущения к авторскому миропониманию все же состоялся, то уместно говорить о национальной 
литературе. Понятие «этническая литература» артикулирует принцип соответствия групповой идентичности, отсылающий к этнокультурным константам, но атрибутивное качество литературы связано с авторским сознанием, индивидуализацией героев, вариативностью типов человеческого поведения и т. д.

При всей взаимопроницаемости «этнического» и «национального» необходимо помнить и об их принципиальном смысловом несовпадении. Если «этническое» подразумевает вневременную устойчивость ментальности как склада мышления, душевных и поведенческих навыков, то «национальное» разворачивается в истории как задача творческая и концептуальная, требующая неослабного и настойчивого стремления не только «быть» (постоянство этнического), но и «стать» (становление, преображение, трансформация). Именно в этой ценностно-смысловой сфере незавершаемого выбора путей развития лежат факторы, конституирующие литературное сознание.

Если литературное сознание, подчеркивал Г.Г. Шпет, «определяется как сознание национальное, т. е. не неопределенно-этническое сознание, а именно национально-историческое...», то логичным представляется отказ от статично понятой идентичности, детерминированной исключительно этнической спецификой, исходя из того, что самобытность национальной культуры, чтобы остаться таковой, требует коммуникативного пространства, иначе говоря - нет идентичности вне контекста коммуникативности, нет диалога вне контекста самоидентификации [26, с. ІІ36].

Проблема, конечно, не том, чтобы поставить под сомнение этнокультурный или региональный дискурсы как таковые. Речь идет о нарастающем методологическом спросе на полноту прочтения текста как обязательного условия полноты описания национальной литературы и, следовательно, на преодоление односторонности и существующего разрыва между аксиологическим и этнокультурным аспектами анализа. Аутентичная оценка произведения возможна при понимании его одновременной принадлежности к сфере этнокультурной непохожести и «зоне действия» художественной аксиологии. Поэтому так важна интегрирующая литературоведческая рефлексия по наболевшим вопросам. Что делает текст, воспринимаемый преимущественно в этнокультурных параметрах, литературой? Не сводим ли мы литературу к «не-литературе», уделяя повышенное внимание внелите- 
ратурным факторам и тем самым косвенно оспаривая устойчивую определенность понятия «национальная литература»? Каков литературоведческий модус описания воплощенных в произведении этнокультурных реалий, если описательность явно превалирует над осмыслением их функциональной роли в многомерной художественной структуре? Как этнокультурный проект в его литературоведческой версии корреспондирует с аксиологическими критериями или дистанцируется от них?

Если мы всерьез озабочены проблемой адекватного восприятия литературного процесса в его живой протяженности во времени, то следует признать насущно необходимым переоткрытие конструктивной соотнесенности понятий «художественная ценность» и «национальное своеобразие», преодолевающее их разрыв. Уместно вспомнить, как в недавнем прошлом заведомо доминантной становилась идейно-тематическая презентация, например, историко-революционного романа, необычайно популярная в национальных литературах - из-за самого факта обращения к подобной тематике эта жанровая разновидность подлежала обязательной позитивной трактовке.

Сегодня мы лучше понимаем, что эстетически ориентированный анализ текста озабочен не столько «вычитыванием» отдельно взятого национального своеобразия, сколько его восприятием в «лабиринте сцеплений», в пространстве внутритекстовых связей и комплементарности всех составляющих художественного мира.

Вопрос, прозвучавший на IV Международном конгрессе компаративистов («Что следует понимать под “национальной литературой”?»), не только выдавал кризис нормативных представлений о предмете изучения, но и приобрел теоретико-методологическую значимость в том смысле, что не исчерпывался фактом сравнительного сопоставления - необходима и взаимодополняемость этнокультурного и аксиологического аспектов изучения, «национального своеобразия» и «художественной ценности», вне которой представление о феномене «национальной литературы» в контексте непрерывно модернизующейся современности будет заведомо неполным.

Современная компаративистика стремится к такому сопряжению «своего» и «чужого», когда потребность национальной литературы в самоосознании и самоопределении нуждается в присутствии и в понимании Другого - иного национального мира, иной художественной реальности, 
иной культуры - с учетом исторически сложившихся ценностно-эстетических ориентиров ${ }^{1}$. В 9о-е гг. XX в. мы пережили угасание интереса друг к другу и, как следствие, обострение проблемы адекватного восприятия иной культурной традиции, нередко подменяемого псевдознанием о Другом, образчик которого представлен в чеховской «Дуэли»: герой «редко видел немцев и не прочел ни одной немецкой книги, но, по его мнению, все зло в политике и науке происходило от немцев. Откуда у него взялось такое мнение, он бы сам не мог сказать, но держался его крепко».

История каждой литературы - не только линейно-фактологическая последовательность событий и изданий, но и выстраданная кристаллизация представлений о художественных ценностях, формирующих внутреннее единство литературы. При определении сущности ценности и ценностных суждений философ-неокантианец Г. Риккерт акцентировал как системообразующий принцип значимости для познающего субъекта [20]². Мыслить аксиологически значит распознавать за летописью литературных фактов иной уровень понимания и сосредоточенности на проблеме ценностных критериев, соотносимых с диалектикой устойчивого и изменчивого, с разграничением доминантных и периферийных факторов развития - с тем, что составляет базовые основания становящейся национальной литературы.

Каждую национальную литературу, отстаивающую свою единственность, уникальность, индивидуальность, отличает складывающаяся иерархия ценностей - разве не предопределяет она особое место Габдуллы Тукая в татарской литературе, Михаила Сеспеля - в чувашской, Алексея Кулаковского - в якутской, Кязима Мечиева - в балкарской, Кузебая Герда в удмуртской? При этом понятие «ценность» не может выступать в роли константы, раз и навсегда наделенной презумпцией значительности, или ассоциироваться с представлением об эталонности на все времена. Историческая подвижность понятия «ценность» как имманентного регулятора ли-

I Cм.: [25; 2I] - эти и некоторые другие работы убедительно подтверждают явно возросший в последние годы научный интерес к компаративистской проблематике. Отметим также коллективные монографии [23, 19, I7, 18, 16].

2 Теория ценностей получила развитие в классических трудах Н. Гартмана («Проблема духовного бытия», «Эстетика»), Р. Лотце («Основание практической философии»), М. Шелера (в Москве в г994 г. изданы его «Избранные произведения»), Р. Ингардена («Исследования по эстетике»), Н. Лосского («Ценность и Бытие»). Из современных исследований обратили на себя внимание: [14, 22, І2]. 
тературной динамики обусловлена борьбой устоявшихся и нарождающихся смыслов, традиционалистских установок и перспективных художественных интенций.

Сама мысль о ценности есть одновременно и мысль о беспощадном суде времени, вердикт которого не подлежит обжалованию, о неотменяемом принципе эстетической избирательности, действующем в теле литературы - именно эта мысль пробуждает и поощряет столь важную для национального самосознания «постоянно возобновляющуюся претензию на всеобщность», о которой писал чешский теоретик Я. Мукаржовский в работе «Может ли эстетическая ценность в искусстве иметь всеобщее значение?» [15, с. 180].

Очевидно, что попытка превратить историю литературы в историю элитарных достижений, внимание только к вершинам, прошедшим испытание временем, существенным образом ограничивают полноценное изучение литературного процесса. Литература, как заметил Ю. Тынянов, не клуб избранных, но она, добавим от себя, и не проходной двор, хотя аксиологический подход, апеллирующий к художественной ценности, действительно не должен замыкаться в модельном ряду.

Смена или переоценка ценностей - движущая сила перемен и показатель парадигмального сдвига в развитии национальной литературы, предопределяющего обновление жанрово- и стилеобразующих факторов литературного развития. Каждая литература проходит через качественные скачки, когда сгущение возможностей эволюционирующего художественного мышления преобразует и модифицирует самосознание литературы, открывая новый горизонт самовыражения и миропонимания. Этот судьбоносный момент становления нового языка самоописания, новой архитектоники смыслов невозможно разглядеть и выделить в потоке литературной эмпирики, если оставаться в ограничительных границах ценностного релятивизма. Литературоведческая аксиология призвана обращать особое внимание на признаки обновляющегося художественного мировидения, художественного открытия как «взрывной» точки литературного развития.

Подтверждая этот тезис, уместно обратиться к творческому опыту, который свидетельствовал о взаимообусловленности этнокультурного различия как основы самоидентификации и художественной результативности. 
Предпочитая расщеплять тот или иной национальный образ мира на строительные компоненты, Г. Гачев при описании художественного мира Ч. Айтматова прибегал к синтезирующему понятию «мироздание по-киргизски», которое поначалу я воспринимал настороженно. По очевидной, как мне казалось, причине: мироздание бытийственно, онтологично, свободно, как и математика, от национальной характерности, всецело принадлежащей сфере исторического развития народов.

Но с другой стороны... Айтматов как художник, укорененный в определенной традиции, смотрел на мир глазами своей культуры, наследуя определенную систему ценностей, сакральных символов, когнитивных установок, восходящих к глубинам мифа, сказки, к великой эпической школе «Манаса» как национального канона. Во-вторых, неологизм «мироздание по-киргизски» фактически возвращал «особенному» качество всеобщности, если, конечно, не упускать из виду решающий критерий художественный потенциал айтматовских текстов, благодаря которому национально-уникальное получало шанс предстать как средоточие целого, обретая масштаб и достоинство общезначимой ценности. Постановка вопроса о «всеобщности» как базовой категории национально-литературного самоопределения утратила бы свою правомерность, если бы абстрагировалась от принципа эстетической состоятельности. Художественное мышление по определению есть мышление интегральное, а художественная мысль есть мысль собирательная, сопрягающая, всеохватывающая.

При всей чуткости к архетипическим культурным моделям, к мифологическому первоистоку (повести «Пегий пес, бегущий краем моря», «Белый пароход»), к ментальным тонкостям, к преданию и ритуалу, Айтматов избегал искушения назидательным этнизмом, вовлекая киргизский мир в горизонт существования рода человеческого. Взятая в своей многомерности художественная мысль не нуждалась в статичной орнаментальности, в «гурманстве по части экзотики», о котором счел нужным сказать С. Аверинцев в статье о Гете и Пушкине, отмечая при этом, что «всечеловечество невозможно без интереса к “местному колориту”, но и несводимо к нему...» [I, с. I94].

Полнота мировосприятия по-айтматовски - это и нравственный долг перед предками, и чувство поколенческой преемственности, и новый тип творческого мышления, для которого нет ничего заведомо неинтересного и заведомо ненужного. Идентификационная точность и то, что называ- 
ют соответствием запросам времени, в айтматовской картине мира находят общий язык. Вовлеченность своего народа в перемены есть вовлеченность своего народа в жизнь человечества. Национальное освобождается от маргинализации, а всеобщность обнаруживает связь с теплой конкретикой домашнего очага.

В прозе Айтматова национально-культурная отличимость предстает не столько как «отдельное» в его непреодолеваемой одинокости, сколько как «особенное», тяготеющее к тому, чтобы стать интересным и важным для всех, стимулом взаимного интереса, не превращаясь в камень преткновения или фактор раздражения, с чем пришлось столкнуться в постайтматовскую эпоху.

Предвижу возражение: сама мысль о всеобности особенного несет в себе элемент нереализуемого утопического благопожелания. Наверное, так оно и есть - еще Ф. Достоевский в статье «Два лагеря теоретиков» (I862) отметил что «народные инстинкты слишком чутки ко всякому посягательству со стороны, потому что иногда рекомендуемое общечеловечным как-то выходит никуда не годным в известной стране и только может замедлять развитие народа, к которому прилагается...» [I3, с. 7]. Но если не задерживаться на пороге элементарной констатации множественности национально-культурных миров и не упускать из виду доминанту и, если хотите, идеал «общего блага», то надо признать, что ссылка на всеобщность меньше всего напоминает абстрагированную «декларацию о намерениях», обнаруживая скорее качество духовной прагматики - особенно для «молодых» литератур в глобализирующемся мире, который технологически сближает, но экзистенциально разъединяет, способствуя трансформации богатства «особенного» в нищету «отдельного».

Когда в интервью «Вопросам литературы» Айтматов утверждал, что его «прежний Шекер включен в духовный круг современных проблем» [3, с. I53], то это было не столько попыткой выдать желаемое за действительное, сколько еще одним подтверждением логики собирательной художественной мысли, предвосхищения соучастия в жизни человечества: специфика, чтобы остаться таковой, должна находить выход в поле межкультурной коммуникации.

В том же интервью привычное для г970-х гг. упоминание неприемлемости «абстрактного, внеисторического и внесоциального понимания 
гуманизма» затем уточняется вполне в духе будущей перестройки, хотя на дворе еще была догорбачевская эра: «...но с другой [стороны. - К.С.] - у нас более широкое, чем прежде, представление о гуманизме». Характерна последующая ссылка на «наших зарубежных коллег», в ряду которых выделены Курт Воннегут и Габриэль Маркес: «Не только мы, но и они сами побуждают нас искать общие точки соприкосновения» [3, с. I6I]. Через несколько лет в другой беседе, опубликованной в «Литературной газете» под названием «Цена - жизнь», Айтматов заявил о своем неприятии «тенденции видеть свой народ только на доске почета», которая становится «тормозом на пути обновления» [4].

В непротиворечивом единстве сводит художник поэзию национальной действительности, экзистенциальную проблематику, чуткость к раскрепощенному чувству, к социально-психологическим коллизиям и потрясениям (в первых повестях, как правило, война и тяжелейшая работа в ее тылу). Айтматов привнес в литературу новую темпоральность, ориентированную на совмещение ритмов традиции и прогресса. Время, утрачивая линейность и заданную целесообразность, стало восприниматься как веер потенциальных возможностей, что само по себе «подстегивало» интерес к вариативности национального бытия, исключающей монополизацию того или иного выбора в качестве окончательного. Он чувствовал напряженную амбивалентность усложняющегося национального бытия, опознавая обновленческие признаки и сдвиги в национальной психологии.

Начиная с первых (I958) публикаций в журналах «Октябрь» и «Новый мир» («Лицом к лицу», «Джамиля»), Айтматов понял, что дело не в апологии застывших в своей этнокультурной непререкаемости истин, а в энергетике творческого продления традиции в новых условиях, сдвигая центр тяжести в сферу подвижной диалектики неизменного - изменяющегося, константного - вариативного. Каждое его произведение было тем или иным по художественному потенциалу ответом на вопросы Кемеля из повести «Верблюжий глаз»: «О Анархай, о великая степь! Что же ты молчишь, о чем думаешь? Что таишь ты в себе от века и что ждет тебя впереди?» [2, T. I, C. 2I6].

Прозаик оставался верным тому, что, предельно обобщая, можно назвать онтологией национального бытия, той шкалой ценностей, отказ от которой равнозначен катастрофическому слому идентичности. Но ему 
близка и прагматика национального бытия, которая не останавливается перед переоценкой ценностей, обновляющей социокультурное пространство. Отсюда чувствительность художника к местам разрыва социокультурной ткани. После конфликта с Абакиром Кемеля охватило «одно желание: уйти, уйти отсюда как можно быстрее, и пусть этот проклятый Анархай любуется моим затылком <...> Почему я, оскорбленный и униженный, должен мерить эти бесконечные седые просторы горькой полыни? И что, спрашивается, надо здесь человеку? Разве мало ему места на земле?» Но, преодолевая давление обстоятельств и не приемля цинизм Абакира, герой спасает себя возвращением на круги своя, совершая духовно значимый поворот, столь важный в айтматовской шкале ценностей: «Беспредельные анархайские просторы раздвинулись еще шире, стали еще привольнее... Я снова почувствовал в себе силу, я тоже воспрянул духом, снова ожили во мне мечты о стране Анархай...» [2, т. I, с. 219, 229, 230].

Уже в первых повестях с их психологически напряженными сюжетными поворотами, с их выпадением из соцреалистической рамки ощущался этот модус открытости, незавершенности национального бытия. Отсюда смысловая полицентричность, сталкивающая характеры, прорвавшиеся голоса человеческого «Я», выпадающие из ритма или гнезда традиционализма.

Исчезновение Джамили и Данияра («Джамиля») сравнимо с травматическим шоком, который вызвал привычно ожидаемую оценку: «- Дура она! Ушла из такой семьи, растоптала счастье свое! - На что позарилась? Ведь у него добра только шинелишка да дырявые сапоги!» [2, т. I, с. І2г]. Юный повествователь тут же откомментировал: «Пусть на Данияре старая шинель и дырявые сапоги, но я-то ведь знал, что душой он богаче всех нас. Нет, не верилось мне, что Джамиля будет несчастна с ним». В «Первом учителе» пробивается неожиданно свободный голос Алтынай: «Токол вторая жена. О, как ненавижу я это слово! Встаньте, несчастные, из могил, встаньте, призраки загубленных, поруганных, лишенных человеческого достоинства женщин! Это говорю я, последняя из вас, перешагнувшая через эту судьбу!» [2, т. I, с. 274].

Сюжет мог разворачиваться в Анархайской степи или в «нашем аиле Куркуреу», на «материнском поле» или в сарозеках из романа «И дольше века длится день», но духовная картография или художественная страте- 
гия Айтматова таковы, что не возникает ощущение окраинности, периферийности. Читатель не чувствует географических, пространственных, этнокультурных ограничений, предлагающих только «гурманство по части экзотики». Анархай, как и Куркуреу, как и родовое кладбище Анна-Бейит, ставшее космодромом - центр «мироздания по-киргизски». Оно получает свое самосознание, свой язык самописания через характерологическую индивидуальность и поступки Толгонай, Данияра, Танабая, Дюйшена, Джамили, этой, по Г. Гачеву, девушки-джигита. При всей заведомой правильности идеологических деклараций Дюйшена в «Первом учителе» происходит их десакрализация в процессе свободного личностного выбора Дюйшена и Алтабай.

Выделим перформативность - деятельностную функцию художественного слова, когда поступок и высказывание айтматовского героя создают прецедент, открывающий новый горизонт. В ситуации духовно-психологического перекрестка, существования на грани, неизбежного перелома повседневности заявляет о себе выход за пределы, причем не только за границы традиционного уклада и поведенческого стереотипа, но и за личностные самоограничения. В «Джамиле» юный повествователь «впервые почувствовал тогда, как проснулось во мне что-то новое, чего я еще не умел назвать, но это было что-то неодолимое, это была потребность выразить себя». Нравственные запросы Данияра и Джамили требуют преодоления того, что казалось фатально непреодолимым. Мотив перехода границы как акта долгожданной, открытой будущему трансгрессии определил тональность и «Первого учителя»: «Сам того не ведая, Дюйшен совершил подвиг $<. .>$ в те дни нам, киргизским детям, нигде не бывавшим за пределами аила, $<. .>$ вдруг открылся новый, неслыханный и невиданный прежде мир...» [2, T. I, c. 257].

Жизнепространство айтматовского метатекста организуют две ключевые и взаимоподсвечивающие метафоры: белая птица Доненбай, не устающая задавать свой судьбоносный вопрос «Чей ты?», и железная дорога, рассекающая и раздвигающая «материнское поле» до ранее неведомого и пугающего горизонта, символизирующая присутствие и наступление другого мира.

Устойчивый образ железной дороги, уходящей вдаль, олицетворяет возможную осуществимость новой жизни. Данияр и Джамиля, не огляды- 
ваясь, «уходили в сторону железнодорожного разъезда». В «Материнском поле» Толганай добирается до неблизкой станции, чтобы повидаться с ушедшим на фронт сыном, но становится испуганным свидетелем только мимо летящих поездов - один из лучших эпизодов в произведениях Айтматова по силе художественной выразительности. Или пролог и эпилог «Первого учителя»: «темная черточка железной дороги, уходящей за горизонт ...» и финальный «поезд <...> понес меня по равнинам казахской степи к новой жизни...» [2, т. I, с. 4I, 279].

Поезд, уносящий героя, - сквозной образ, синонимически соотнесенный с «колесом времени» из романа «И дольше века длится день», которое «убыстряется», побуждая Едигея вновь и вновь задавать себе сакраментальный вопрос: «почему они <дети> стали такими?» За ним острота выбора между обезличенностью, когда родовое кладбище Ана-Бейит перестает быть таковым, а сыромятная верблюжья кожа, отбивающая память, плодит манкуртов, и самосохранением, суть которого сформулировал тот же Едигей: «...не идите против человеческого обычая...» [2, т. 2, с. 474].

Казалось бы, обычай, как и все в мире, подвержен изменениям и тот или иной обычай вполне может превратиться в анахронизм. Но Айтматов смотрит глубже, улавливая онтологически значимые для народа и человека смыслы. «Идти против» в контексте его центральной художественной идеи от «Джамили» до «И дольше века длится день» - значит, как сказано в романе, «отбить человеку память, разрушить в нем разум, вырвать корни того, что пребывает с человеком до последнего вздоха, оставаясь его единственным обретением, уходящим вместе с ним и недоступным для других».

Генетическая память приаральского казаха Едигея и философия забвения или расчеловечивания человека, воплощенная в мироощущении Сабитжана, полемически противостоят друг другу, приобретая в художественном мире Айтматова парадигмальное значение. Похороны отца для Сабитжана формальная обязанность, но для Едигея, озабоченного сохранением порядка слов в молитве, - нравственный закон, предписывающий похоронить Казангапа именно на Ана-Бейит.

Распад патриархальной цельности - трещина, проходящая через сердце Едигея, но есть и другая сторона медали - на заброшенном родовом кладбище, далеком от цивилизационных центров, сходятся этос и ракета, архаика и современность, локальный обычай и планетарная технология. 
Айтматов явил такой уровень миропонимания, когда они вдруг перестают быть некими полюсами, антиномиями, тезисом-контртезисом, обнаруживая взаимозависимость, вне которой уже не дано найти ответ на вопрос «почему... стали такими?».

Полет ракеты - то, что казалось Едигею «посторонним» делом, коснулся и его: в финале человек, верблюд, собака - родственные души, учуявшие общую для всех угрозу, - бегут от космодрома, от «сокрушающего грохота» иного мира. И все-таки в финале дочери не застают Едигея дома: он, оглушенный, но не сломленный, уехал-таки бороться за спасение Ана-Бейит.

Лицом к лицу, если заимствовать название айтматовской повести, сходятся конкурирующие смыслы, альтернативные состояния жизни. Бескомпромиссный спор жизненных установок с наибольшей и поучительной наглядностью представлен в той сцене, когда иноходец Гульсары («Прощай, Гюльсары»), не мог идти дальше и «остановился совсем. - Иди как можешь, я буду сзади, я не брошу тебя, - сказал Танабай». Из проезжавшей мимо машины вышел водитель и предложил подбросить до совхоза, но вот ответ недостаточно современного Танабая: «- Спасибо. Я с конем. - Да брось ты его к собакам, столкни вон в овраг. Хочешь, поможем? - Поезжай, - мрачно процедил Танабай». Знаковый диалог продолжился в отъехавшей машине: «- Зачем смеешься над человеком, а если бы тебе так пришлось? - сказал попутчик, сидевший рядом с шофером. - Подумаешь, кляча какая-то! Пережитки прошлого. Сейчас, брат, техника всему голова. А таким старикам и лошадям конец пришел» [2, т. I, с. 395, 397].

Запомнившаяся по «Первому учителю» тональность - «чего ради ты мыкаешься с этой школой, с ребятишками несмышлеными?» [2, т. I, c. 26I] - отозвалась и в повести о легендарном коне и его человеческом побратиме: чего ради мыкаешься с Гульсары?

Примитивно-утилитарный взгляд на вещи выдает не столько свободу от прошлого, сколько элементарный аморализм и убогую однозначность, которой только и дано упрощать и умалять реальную сложность жизни. Как человек и художник, Айтматов не мог примириться с таким псевдорационализмом, с такой перекодировкой сознания, когда человек вспоминающий, не забывающий свое имя и свой род, не оставляющий в беде другое живое существо вдруг оказывается невостребованным, «выпадая» из современности. 
Он отчетливо понимал, что отказ от базовых ценностей равнозначен катастрофическому слому идентичности, но, повторим, идентификационной достоверности его письма сопутствовало ощущение внутренней противоречивости усложнявшегося национального бытия. Пронизанность смысловыми притяжениями-отталкиваниями отличает и «нарративную стратегию» Айтматова, чуткого к признакам лиминальности (пороговости, переходности) национального мира или, как предпочитают изъясняться этнологи, исходной аутентичной культуры местного населения. Одним из первых в «советской многонациональной литературе» он остро ощутил обостренную амбивалентность ускоряющегося настоящего, инициирующую то, что сегодня назвали бы кризисом идентичности или зоной, по словам франкоязычного уроженца Мартиники и борца за деколонизацию Франца Фанона, «потаенной нестабильности, где народ находится» [5, с. 90].

Драматизм и сложность ситуации состояли в том, что классическая идея поступательного и необратимого прогресса перестала «работать», а изменения и разрывы никак не продуцировались изнутри пережитым и накопленным опытом, появляясь со стороны, не обусловленные местными ожиданиями или всё еще не утраченным чувством социальной справедливости. Гуманистический алармизм киргизского писателя подпитывался надвигавшейся энтропией традиционных ценностей, перспективой обесценивания традиции, которая лишалась прописки в современном мире, проходя больше по разряду «культурный атавизм».

Айтматову важно было сохранить иное восприятие традиции - как залога непрерывности существования народа или, если хотите, страховки от распыления национального духа. В то же время он не мог не понимать, что судьбоносный вопрос выживаемости и жизнеспособности национального мира не сводится только к сбережению традиционно действующих регуляторов жизненного уклада. Чувство защищенности, издавна гарантированное властью обычая, стало покидать человека...

Останется ли «мироздание по-киргизски»...

На языке тревог и надежд $\mathrm{XX}$ в. перспективно мыслящий художник не уставал подтверждать национально-культурную индивидуальность народа как достояние человечества. Его ценностные ориентиры всерьез противостояли мифу о внеисторическом характере жизни малочисленных народов - внеисторическом в духе размышлений полковника Верховского 
из повести А. Бестужева-Марлинского «Аммалат-бек», который любил порассуждать об «изумительной неподвижности азиатского быта», принадлежащей «не времени, а месту... печальная история!» [8, с. 525].

Уязвимость национальных культур в современном мире и повышенный болевой порог их создателей обостренно ощущал в последние годы жизни Г. Гачев с его «трепетным отношением к уникальности». Отстаивая феномен национального, он не уставал подчеркивать, что «ради самосохранения своего художественная литература заинтересована в том, чтобы не растаяли нации». При этом он не избегал дискомфортной мысли о хрупкости и возможной смерти национальных миров, которые стали интерпретироваться как безнадежно архаичные в эпоху транскультурного человечества и унифицирующей глобализации с ее, по Гачеву, «вселенской смазью» беспочвенности, усредненности, стандартизации. Его любимый сакраментальный вопрос - «Как добраться до тончайшего и неуловимого?» - все определеннее приобретал катастрофические обертоны: до чего добираться, если сам национальный мир под угрозой исчезновения... Он называл этот тренд главной мировой проблемой, а свою работу с национальными образами - лебединой песней, так и не примирившись с «силой вещей», с явной решимостью формулируя иную и по сути антиглобалистскую позицию: «отсталая» национальная культура в сравнении с «универсалистской» современной - это скрипка Страдивари и Амати рядом с массовым фабричным производством стандартных скрипичных изделий» [ІІ, с. 429, 324, 58, 27].

В айтматовском опыте позитивной идентичности принцип самоуважения и переживание своей «малости», точнее - «самости» поддержаны четко артикулированным чувством границы, отделяющей национальное как созидательную творческую задачу от неплодотворной националистической узости, разобщающей людей и культуры.

Поиск «объективных закономерностей мирового литературного процесса», отмечал Ю. Виппер во вступительных замечаниях к первому тому «Истории всемирной литературы», должен включать в себя опыт «так называемых “малых” литератур», которые «могут иногда выдвигать художественные ценности мирового значения и служить почвой для таких обобщений, без которых в наших представлениях об этом процессе существовали бы серьезные изъяны». И далее: «..такой подход помогает преодолеть 
одинаково односторонние и в научном отношении пагубные крайности как европоцентризма, так и востокоцентризма» [Іо, с. 7]. Точно выбранная интонация - так называемые, да и слово «малые» в кавычках - отменяла фактор малости, определявший вектор все еще популярной дифференциации народов и культур на исторические и неисторические, передовые и отсталые. Эта методологически конструктивная и перспективная характеристика была инспирирована литературной практикой представителей «так называемых малых» литератур, в ряду которых непременно упоминался и Ч. Айтматов.

Каждая эпоха привносит свои акценты, раздвигая смысловые границы и возвращая в сферу анализа ускользавшие ранее смысловые оттенки. Содержательная двойственность ценностного подхода состоит в соотнесенности двух планов: выделение текста как состоявшегося явления литературы и актуализация принципа его смысловой неисчерпаемости, иначе говоря - неизолированности от любого вновь возникающего контекста, открытости для каждой новой интерпретации. Текст как «художественная ценность» - средоточие не только смыслов, заново или впервые открываемых в смене историко-литературных контекстов, но и множественности потенциальных трактовок, ни одна из которых не может претендовать на роль последней смысловой инстанции.

В данном контексте не стоит недооценивать следующее обстоятельство: ни в одной, наверное, области гуманитарного знания не накопилось столько «сгустков», как в изучении литератур народов России. К слову «сгусток», как известно, прибегнул Ю. Тынянов в своей полемике с В. Белинским, который «отважно написал вздор о XVIII веке», утверждая, что «у нас нет литературы». «У нас, - утверждал Ю. Тынянов в статье “Промежуток” (I924), - одна из величайших стиховых культур; она была движением», но «на нас этот стих падает как сгусток, как готовая вещь, и нужна работа археологов, чтобы в сгустке обнаружить когда-то бывшее движение» [24, с. I72].

Пробуждение «бывшего движения» становится возможным, если перечитывание, в том числе хрестоматийных текстов, всерьез превращается в акт переосмысления, отвоевывавшего «спящие» смыслы у забвения - будь это столь значимые для литератур Севера мифопоэтическая традиция, ритуальные тонкости шаманизма, завещанный предками культ слова как сакраментальной ценности («нельзя, - говорят ненцы, - играть Словом») 
или заново «прочитанный» общетюркский контекст различных национальных литератур.

Смена парадигмы - от самодостаточного этнокультурного дискурса к интегрирующему литературоведческому мышлению - поможет «снять» знакомое современным исследователям ощущение методологического кризиса, расширяя спектр возможностей национального литературоведения, способствуя обновлению языка описания произведения как художественной структуры и литературного процесса как содержательной целостности. Эта соразмерность предполагает продвижение к союзу диахронии и синхронии как основе системного подхода и реконструкцию целостности историко-культурного процесса, учитывая теоретико-методологическую недостаточность редукции художественной многомерности к той или иной этнокультурной версии.

В формировании новой парадигмы в изучении наших национальных литератур определяющим должен стать принцип ключевой триады гуманитарного знания - «идентичность», «художественная ценность», «межкультурный диалог». Их изучение, ориентированное на restituto in integro (восстановление в целостности), и выявление фундаментальных ценностных ориентиров воспринимаются как грани единого подхода, без которого призыв к полноте описания каждой национальной литературы останется всего лишь благим пожеланием.

\section{Список литературы}

I Аверинцев С.С. Гете и Пушкин (I749-I799-I999) // Новый мир. I999. № 6. URL: http://magazines.russ.ru/novyi_mi/r999/6/averinz.html (дата обращения: OI.I2.20I7)

2 Айтматов Ч.Т. Собр. соч.: в 3 т. М.: Молодая гвардия. І982. 607 с. + 495 с. +575 с.

3 Айтматов Ч.Т. Точка присоединения. Беседу вел В. Левченко // Вопросы литературы. І976. № 8. С. 146-і70.

4 Айтматов Ч.Т. Цена - жизнь. Беседу вела И. Ришина // Литературная газета. 198г. гз августа.

5 Баба X. ДиссемиНация: время, повествование и края современной нации // Синий диван. 2005. № 6. С. 68-ІІ18.

6 Бахтин М.М. Эстетика словесного творчества. М.: Искусство, I979. 424 с.

7 Бердяев Н.А. Судьба России. М.: Сов. писатель, г990. 346 с. 
Бестужев-Марлинский А.А. Соч.: в 2 т. М.: ГИХЛ, І958. Т. І. 630 с.

9 Виноградов И.А. Вопросы марксистской поэтики. М.: Сов. писатель, 1972. 423 с.

Iо Bunnер Ю.Б. Вступительные замечания // История всемирной литературы: в 9 т. М.: Наука, І983. Т. г. С. 5-12.

II Гачев Г.Д. Национальные образы мира. М.: Сов. писатель, I988. 233 с.

I2 Докучаев И.И. Ценность и экзистенция. Основоположения исторической аксиологии культуры. СПб.: Наука, 2009. 595 с.

I3 Достоевский Ф.М. Полн. собр. соч.: в 30 т. Л.: Наука, I980. Т. 20. 432 с.

I4 Жизнь как ценность / отв. ред. Л.И. Фесенкова. М.: ИФРАН, 200о. 270 с.

I5 Мукаржовский Я. Исследования по эстетике и теории искусства. М.: Искусство, I994. 606 c.

I6 Национальные литературы республик Поволжья (І980-2ого гг.) / науч. ред. В.Р. Аминева. Барнаул: ИГ «Си-пресс», 2012. 234 с.

I7 Проблемы современной компаративистики / сост. Е. Луценко, И. Шайтанов. М.: Вопросы литературы, 20II. 3I7 с. (Университетская библиотека журнала «Вопросы литературы»)

I8 Проблемы создания региональной истории литератур народов Поволжья: материалы региональной научно-практической конференции / сост. и науч. ред. А.Ф. Мышкина. Чебоксары: Новое время, 2014. 280 с.

I9 Проблемы сравнительного и сопоставительного литературоведения Поволжья: сб. науч. тр. / сост. и науч. ред. А.Ф. Мышкина. Чебоксары: Новое время, 2010. I39 c.

20 Риккерт Г. Границы естественно-научного образования понятий: Логическое введение в исторические науки. СПб., І903. 615 c.

2I Родионов В.Г. Чувашское сравнительное литературоведение. Теория и практика. Чебоксары: Новое время, 20I7. 9I с.

22 Розов Н.С. Ценности в проблемном мире: философские основания и социальные приложения конструктивной аксиологии. Новосибирск: НГУ, г998. 523 с.

23 Русская и сопоставительная филология: состояние и перспективы: Международная научная конференция, посвященная 2оо-летию Казанского университета (Казань, 4-6 октября 2004 г.): Труды и материалы / Казан. гос. ун-т; под общ. ред. К.Р. Галиуллина. Казань: Казан. гос. ун-т им. В.И. Ульянова-Ленина, 2004. 364 c.

24 Тынянов Ю.Н. Поэтика. История литературы. Кино. М.: Наука, I977. 575 с.

25 Шайтанов И.О. Компаративистика и/или поэтика. Английские сюжеты глазами исторической поэтики. М.: РГГУ, 20Іо. 656 с.

26 Шиет Г.Г. История как проблема логики. Критические и методологические исследования: в 2 ч. М.: Памятники исторической мысли, 2002. II68 c. 


\section{References}

I Averintsev S.S. Gete i Pushkin (I749-I799-I999) [Goethe and Pushkin]. Novyi mir, I999, no 6. Available at: http://magazines.russ.ru/novyi_mi/r999/6/averinz.html (Accessed or December 20I7). (In Russ.)

2 Aitmatov Ch.T. Sobranie sochinenii: $v 3 t$. [Works: in 3 vols.]. Moscow, Molodaia gvardiia Publ., I982. 607 p. + 495 p. + 575 p. (In Russ.)

3 Aitmatov Ch.T. Tochka prisoedineniia. Besedu vel V. Levchenko [The point of connection. Interview by V. Lechenko]. Voprosy literatury, I976, no 8, pp. I46-I70. (In Russ.)

4 Aitmatov Ch.T. Tsena - zhizn'. Besedu vela I. Rishina [The price is life. Interview by I. Richina]. Literaturnaia gazeta, 198I, August I3. (In Russ.)

5 Baba Kh. DissemiNatsiia: vremia, povestvovanie i kraia sovremennoi natsii [Bhabha H. DissemiNation: Time, narrative and the margins of the modern nation]. Sinii divan, 2005, no 6, pp. 68-II8. (In Russ.)

6 Bakhtin M.M. Estetika slovesnogo tvorchestva [The aesthetics of verbal art]. Moscow, Iskusstvo Publ., I979. 424 p. (In Russ.)

7 Berdiaev N.A. Sud'ba Rossii [The fate of Russia]. Moscow, Sovetskii pisatel' Publ., I990. 346 p. (In Russ.)

8 Bestuzhev-Marlinskii A.A. Sochineniia: $v 2$ t. [Works: in 2 vols.]. Moscow, GIKhL Publ., I958. Vol. I. 630 p. (In Russ.)

9 Vinogradov I.A. Voprosy marksistskoi poetiki [The questions of Marxian poetics]. Moscow, Sovetskii pisatel' Publ., I972. 423 p. (In Russ.)

Io Vipper Iu.B. Vstupitel'nye zamechaniia [Introduction, notes]. Istoriia vsemirnoi literatury: $v 9 t$. [History of the world literature: in 9 vols.]. Moscow, Nauka Publ., I983, vol. I, pp. 5-I2. (In Russ.)

II Gachev G.D. Natsional'nye obrazy mira [National images of the world]. Moscow, Sovetskii pisatel' Publ., I988. 233 p. (In Russ.)

I2 Dokuchaev I.I. Tsennost' i ekzistentsiia. Osnovopolozheniia istoricheskoi aksiologii kul'tury [Value and existentia. The bases of historical axiology of culture]. St. Petersburg, Nauka Publ., 2009. 595 p. (In Russ.)

I3 Dostoevskii F.M. Polnoe sobranie sochinenii: $v$ so t. [Complete works: in 30 vols.]. Leningrad, Nauka Publ., I980. Vol. 20. 432 p. (In Russ.)

I4 Zhizn' kak tsennost' [Life as value], ed. L.I. Fesenkova. Moscow, IFRAN Publ., 2000. 270 p. (In Russ.)

I5 Mukarzhovskii Ia. Issledovaniia po estetike i teorii iskusstva [Studies in the aesthetics and theory of art]. Moscow, Iskusstvo Publ., I994. 606 p. (In Russ.)

I6 Natsional'nye literatury respublik Povolzh'ia (1980-20Io gg.) [National literatures of Povolzh'e republic], ed. V.R. Amineva. Barnaul, IG “Si-press” Publ., 20I2. 234 p. (In Russ.) 
I7 Problemy sovremennoi komparativistiki [The problems of contemporary comparative studies], eds. E. Lutsenko, I. Shaitanov. Moscow, Voprosi literaturi Publ., 20II. 3 I7 p. (Universitetskaia biblioteka zhurnala "Voprosi literature" [The university library of the journal Voprosi literaturi]). (In Russ.)

I8 Problemy sozdaniia regional'noi istorii literatur narodov Povolzh'ia: materialy regional'noi nauchno-prakticheskoi konferentsii [The problems of development of the regional literary history of Povolzh'e nations: regional conference proceedings], ed.

A.F. Myshkina. Cheboksari, Novoe vremia Publ., 20I4. 280 p. (In Russ.)

I9 Problemy sravnitel'nogo i sopostavitel'nogo literaturovedeniia Povolzh'ia: sb. nauch. tr. [The problems of comparative literary studies in Povolzhye: collection of works], ed. A.F. Myshkina. Cheboksari, Novoe vremia Publ., 20Io. I39 p. (In Russ.)

20 Rikkert G. Granitsy estestvenno-nauchnogo obrazovaniia poniatii: Logicheskoe vvedenie v istoricheskie nauki [The boundaries of naturally-scientific emergence of concepts: logic introduction into historical sciences]. St. Peterburg, I903. 6I5 p. (In Russ.)

2I Rodionov V.G. Chuvashskoe sravnitel'noe literaturovedenie. Teoriia i praktika [Chuvash comparative literary studies: theory and practice]. Cheboksari, Novoe vremia Publ., 20I7. 9I p. (In Russ.)

22 Rozov N.S. Tsennosti v problemnom mire: filosofskie osnovaniia $i$ sotsial'nye prilozheniia konstruktivnoi aksiologii [Values in the troubled world: philosophical grounds and the development of constructive axiology appendix]. Novosibirsk, NGU Publ., I998. 523 p. (In Russ.)

23 Russkaia i sopostavitel'naia filologiia: sostoianie i perspektivy: Mezhdunarodnaia nauchnaia konferentsiia, posviashchennaia 20o-letiiu Kazanskogo universiteta (Kazan', 4-6 oktiabria 2004 goda): Trudy i materialy [Russian and comparative literary studies: state of art and perspectives: International conference in honor of the 200-year anniversary of the Kazan University], Kazan State University; ed. K.R. Galiullina. Kazan, Kazan. gos. un-t im. V.I. Ul'ianova-Lenina Publ., 2004. 364 p. (In Russ.)

24 Tynianov Iu.N. Poetika. Istoriia literatury. Kino [Poetics. Literary history. Cinema]. Moscow, Nauka Publ., I977. 575 p. (In Russ.)

25 Shaitanov I.O. Komparativistika i/ili poetika. Angliiskie siuzhety glazami istoricheskoi poetiki [Comparative studies and/or poetics. English plots in the perspective of historical poetics]. Moscow, RGGU Publ., 20I0. 656 p. (In Russ.)

26 Shpet G.G. Istoriia kak problema logiki. Kriticheskie i metodologicheskie issledovaniia: $v 2 \mathrm{ch}$. [History as a problem of logic. Critical and methodological studies in 2 parts]. Moscow, Pamiatniki istoricheskoi mysli Publ., 2002. II68 p. (In Russ.) 